Received: 19 November 2018

Accepted: 24 April 2019

Published online: 06 May 2019

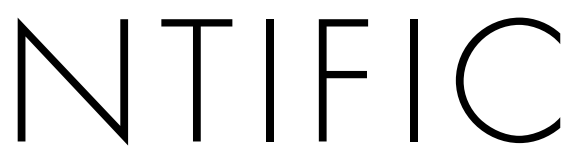

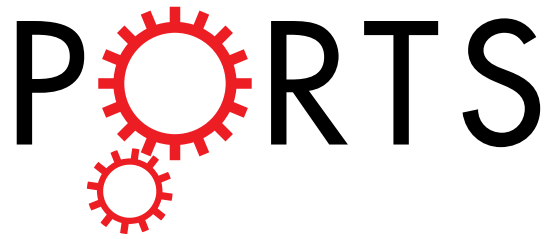

\title{
OPEN The dynamic relationships between the active and catabolic vitamin $D$ metabolites, their ratios, and associations with PTH
}

Jonathan C.Y. Tang $\mathbb{1}^{1}$, Sarah Jackson ${ }^{2}$, Neil P. Walsh ${ }^{3}$, Julie Greeves ${ }^{2}$, William D. Fraser ${ }^{1,4}$ \& Bioanalytical Facility team*

Vitamin D status, assessed by serum concentration of $25(\mathrm{OH}) \mathrm{D}$, is the prime candidate marker for many disease-association studies, but the interplay between the subsequent 1,25-dihydroxyvitamin $\mathrm{D}\left(1,25(\mathrm{OH})_{2} \mathrm{D}\right)$ and 24,25 -dihydroxyvitamin $\mathrm{D}\left(24,25(\mathrm{OH})_{2} \mathrm{D}\right)$ metabolites is unclear. In this study, we conducted an analysis from a large cohort of healthy, physically fit, young army recruits $(n=940)$. We found a significant, inverse relationship between serum $25(\mathrm{OH}) \mathrm{D}$ and $1,25(\mathrm{OH})_{2} \mathrm{D}: 24,25(\mathrm{OH})_{2} \mathrm{D}$ vitamin $D$ metabolite ratio (VMR) $\left(r^{2} \operatorname{Exp}=0.582, p<0.0001\right)$, and demonstrated a significant association with increasing PTH concentration $(p<0.001)$. Circannual rhythms were evident for all vitamin $D$ metabolites and VMRs except for $1,25(\mathrm{OH})_{2} \mathrm{D}$ when fitted to Cosinor curves. We estimated $1,25(\mathrm{OH})_{2} \mathrm{D}: 24,25(\mathrm{OH})_{2} \mathrm{DVMR}$ of $\geq 35$ to be the threshold value for vitamin $\mathrm{D}$ insufficiency, and $\geq 51$ to be predictive of vitamin $D$ deficiency. Our three-dimensional model provides mechanistic insight into the vitamin D-PTH endocrine system, and further substantiates the role of $24,25(\mathrm{OH})_{2} \mathrm{D}$ in human physiology. The model sets a new paradigm for vitamin $D$ treatment strategy, and may help the establishment of vitamin D-adjusted PTH reference intervals. The study was approved by the UK Ministry of Defence research ethics committee (MODREC 165/Gen/10 and 692/MoDREC/15). ClinicalTrials.gov Identifier NCT02416895.

The vitamin D pathway is a dynamic system, and its functional role in bone health and other diseases is the subject of intense research. Associations of vitamin D deficiency with a wide spectrum of disease states have drawn attention from the scientific community and increasing awareness of the general population. Despite vitamin D deficiency being a global public health concern, the approach through improving vitamin D status by supplementation, dietary intake and increased sunlight exposure, has resulted in mixed outcomes ${ }^{1-3}$. The contradictory evidence has prompted studies on the metabolites of vitamin $\mathrm{D}$. The most abundant metabolite in circulation is 25-hydroxyvitamin $\mathrm{D}(25(\mathrm{OH}) \mathrm{D})$, which exists in two major forms: 25-hydroxycholecalciferol $(25(\mathrm{OH}) \mathrm{D} 3)$ and 25-hydroxyergocalciferol $(25(\mathrm{OH}) \mathrm{D} 2)$. Measurement of serum total $25(\mathrm{OH}) \mathrm{D}(\mathrm{D} 3+\mathrm{D} 2)$ is the barometer of vitamin D status; concentrations $\leq 30 \mathrm{nmol} / \mathrm{L}$ and between $30-50 \mathrm{nmol} / \mathrm{L}$ are defined as deficient and insufficient, respectively by the U.S Institute of Medicine (IOM) ${ }^{4}$ and the UK National Osteoporosis Society (NOS) ${ }^{5}$. 1,25 -dihydroxyvitamin $\mathrm{D}\left(1,25(\mathrm{OH})_{2} \mathrm{D}\right)$ is synthesised by the hydroxylation of $25(\mathrm{OH}) \mathrm{D}$ through the actions of $1 \alpha$-hydroxylase produced in the renal tubules. $1,25(\mathrm{OH})_{2} \mathrm{D}$ is the most biologically active form of vitamin $\mathrm{D}$ and circulates in pmol/L concentration; it controls intestinal absorption of calcium and phosphate, stimulates osteoclast activity, and helps regulate the release of parathyroid hormone $(\mathrm{PTH})$. Although $1,25(\mathrm{OH})_{2} \mathrm{D}$ is derived from $25(\mathrm{OH}) \mathrm{D}$, there is no direct correlation in serum concentrations between the two vitamin $\mathrm{D}$ metabolites except in patients with chronic kidney disease $(\mathrm{CKD})^{6}$, where a greater association is observed between $1,25(\mathrm{OH})_{2} \mathrm{D}$ and $25(\mathrm{OH}) \mathrm{D}$, dependent upon the severity of the renal impairment. The lack of a direct relationship, despite their close proximity in the metabolic pathway, is due to the tight regulation of the hydroxylation enzymes

${ }^{1}$ Norwich Medical School, University of East Anglia, Norwich Research Park, Norwich, UK. ${ }^{2} \mathrm{HO}$ Army, Andover, UK. ${ }^{3}$ College of Human Sciences, Bangor University, Bangor, UK. ${ }^{4}$ Departments of Diabetes, Endocrinology and Clinical Biochemistry, Norfolk and Norwich University Hospital NHS Foundation Trust, Colney Lane, Norwich, UK. *A comprehensive list of consortium members appears at the end of the paper. Correspondence and requests for materials should be addressed to J.C.Y.T. (email: Jonathan.Tang@uea.ac.uk) 


\begin{tabular}{|l|l|l|l|l|l|l|l|l|l|}
\hline Profile & mean & SD & Min & $\begin{array}{l}\mathbf{2 . 5}^{\text {th }} \\
\text { Percentile }\end{array}$ & $\begin{array}{l}\mathbf{2 5}^{\text {th }} \\
\text { Percentile }\end{array}$ & Median & $\begin{array}{l}\mathbf{7 5}^{\text {th }} \\
\text { Percentile }\end{array}$ & $\begin{array}{l}\mathbf{9 7}^{\text {th }} \\
\text { Percentile }\end{array}$ & Max \\
\hline $25(\mathrm{OH}) \mathrm{D}, \mathrm{nmol} / \mathrm{L}$ & 62.4 & 29.8 & 6.9 & 18.1 & 39.8 & 59.2 & 81.0 & 130.9 & 222.5 \\
\hline $24,25(\mathrm{OH})_{2} \mathrm{D}, \mathrm{nmol} / \mathrm{L}$ & 5.4 & 3.3 & 0.5 & 1.0 & 2.9 & 4.9 & 7.4 & 13.0 & 29.6 \\
\hline $1,25(\mathrm{OH})_{2} \mathrm{D}, \mathrm{pmol} / \mathrm{L}$ & 138.8 & 39.6 & 32.3 & 71.9 & 111.0 & 135 & 161.0 & 229.7 & 380.0 \\
\hline $25(\mathrm{OH}) \mathrm{D}: 24,25(\mathrm{OH})_{2} \mathrm{D}$ VMR & 13 & 4 & 2 & 7 & 10 & 12 & 15 & 25 & 39 \\
\hline $1,25(\mathrm{OH})_{2} \mathrm{D}: 24,25(\mathrm{OH})_{2} \mathrm{D}$ VMR & 38 & 33 & 5 & 9 & 18 & 28 & 45 & 132 & 300 \\
\hline Intact PTH, $\mathrm{pmol} / \mathrm{L}$ & 3.7 & 1.2 & 1.0 & 1.9 & 2.9 & 3.5 & 4.3 & 6.8 & 11.4 \\
\hline ACa, $\mathrm{mmol} / \mathrm{L}$ & 2.38 & 0.07 & 2.00 & 2.20 & 2.32 & 2.40 & 2.41 & 2.50 & 2.60 \\
\hline
\end{tabular}

Table 1. Distribution of biochemical measurements performed in the study.

expressed by the actions of CYP27B1 and CYP24A1. CYP24A1 produces 24-hydroxylase that converts $25(\mathrm{OH})$ $\mathrm{D}$ into 24,25 -dihydroxyvitamin $\mathrm{D}\left(24,25(\mathrm{OH})_{2} \mathrm{D}\right)$. The transcription of the CYP24A1 gene is stimulated by the phosphate-regulating hormone fibroblast growth factor-23 (FGF23), and when PTH is suppressed. The combination results in an increase in serum $24,25(\mathrm{OH})_{2} \mathrm{D}$. We have previously described a concentration-dependent relationship between serum $25(\mathrm{OH}) \mathrm{D}$ and $24,25(\mathrm{OH})_{2} \mathrm{D}^{7}$. We have also reported a patient, presenting with idiopathic infantile hypercalcaemia (IIH), who was diagnosed with biallelic CYP24A1 mutations resulting in the inability to produce $24,25(\mathrm{OH})_{2} \mathrm{D}$ from $25(\mathrm{OH}) \mathrm{D}$, and had an elevated serum $1,25(\mathrm{OH})_{2} \mathrm{D}$ and a persistent state of hypercalcaemia. The use of $25(\mathrm{OH}) \mathrm{D}: 24,25(\mathrm{OH})_{2} \mathrm{D}$ vitamin $\mathrm{D}$ metabolite ratio (VMR) can be a valuable tool in identifying such pathological conditions resulting from impaired CYP24A1 function ${ }^{8,9}$. The use of VMR in the population can provide an assessment of the vitamin D catabolic status; thus allowing a targeted approach to vitamin D supplementation ${ }^{10}$.

In this report, we describe a novel approach to the interpretation of serum $25(\mathrm{OH}) \mathrm{D}$ and $1,25(\mathrm{OH})_{2} \mathrm{D}$ concentrations that incorporates $24,25(\mathrm{OH})_{2} \mathrm{D}$ values. Using data from a large cohort of young healthy adults as our reference population, we report the intricate relationships between active and catabolic forms of vitamin D metabolites, and the influence on PTH.

\section{Results}

Results from 940 participants were included in the data analysis. Statistical analyses on $25(\mathrm{OH}) \mathrm{D}$ and $24,25(\mathrm{OH})_{2} \mathrm{D}$ were performed on the respective total (sum of D3+D2) values, the distributions were untrimmed and no outlier was removed. Summary of the distribution of biochemical profile is shown in Table 1.25(OH)D2 was found in $57.8 \%$ of the subjects, mean (range) of $4.2 \mathrm{nmol} / \mathrm{L}(0.6-29.1) .24,25(\mathrm{OH})_{2} \mathrm{D} 2$ was found in $0.4 \%$ of the subjects, mean (range) $1.5 \mathrm{nmol} / \mathrm{L}(1.2-1.8)$.

24, 25(OH) $)_{2} \mathrm{D}$ and $25(\mathrm{OH}) \mathrm{D}$. The mean concentration of $24,25(\mathrm{OH})_{2} \mathrm{D}$ was on average 9.5 -fold lower than $25(\mathrm{OH}) \mathrm{D}$. Linear regression analysis (Fig. 1a) showed a directly proportional relationship between $24,25(\mathrm{OH})_{2} \mathrm{D}$ and $25(\mathrm{OH}) \mathrm{D}$ concentrations: $\left[24,25(\mathrm{OH})_{2} \mathrm{D}\right]=0.0946 \times[25(\mathrm{OH}) \mathrm{D}]-0.42 ; r^{2}=0.7206$. Using this equation, we derived serum $24,25(\mathrm{OH})_{2} \mathrm{D}$ concentration of $\geq 4.3 \mathrm{nmol} / \mathrm{L}$ to be equivalent to the $\mathrm{OM}$ vitamin $\mathrm{D}$ replete status (i.e. $25(\mathrm{OH}) \mathrm{D}$ of $50 \mathrm{nmol} / \mathrm{L}$ ), and $24,25(\mathrm{OH})_{2} \mathrm{D}$ concentration of $\leq 2.4 \mathrm{nmol} / \mathrm{L}$ is equivalent to deficiency status (i.e. $25(\mathrm{OH}) \mathrm{D}$ of $\leq 30 \mathrm{nmol} / \mathrm{L}$ ).

1,25(OH $)_{2} \mathrm{D}$ and 25(OH)D. Despite a direct enzymatic conversion of $25(\mathrm{OH}) \mathrm{D}$ to $1,25(\mathrm{OH})_{2} \mathrm{D}$, we showed no correlation in serum concentrations between these two vitamin D metabolites (Fig. 1b). This finding is consistent with published studies; $1,25(\mathrm{OH})_{2} \mathrm{D}$ is able to directly inhibit the expression of $1 \alpha$-hydroxylase, and indirectly inhibit by suppressing PTH and stimulating FGF23 production ${ }^{11,12}$. This negative feedback system provides an essential safeguard mechanism against hypercalcaemia, hence $1,25(\mathrm{OH})_{2} \mathrm{D}$ concentration is unaffected by the circulatory concentration of $25(\mathrm{OH}) \mathrm{D}$.

25(OH)D:24,25(OH) 2 D VMR and vitamin D status. The $25(\mathrm{OH}) \mathrm{D}: 24,25(\mathrm{OH})_{2} \mathrm{D}$ VMR showed an indirect relationship with $25(\mathrm{OH}) \mathrm{D}$ (Fig. 1c); LOWESS fitting showed a steady increase in $25(\mathrm{OH}) \mathrm{D}: 24,25(\mathrm{OH})_{2} \mathrm{D}$ VMR with the decline in $25(\mathrm{OH}) \mathrm{D}$ concentration. One-way ANOVA showed a significant increase in $25(\mathrm{OH})$ $\mathrm{D}: 24,25(\mathrm{OH})_{2} \mathrm{D}$ VMR $(\mathrm{p}>0.001)$ at $25(\mathrm{OH}) \mathrm{D}$ below $50 \mathrm{nmol} / \mathrm{L}$ (Fig. 2). The greatest increase was observed when $25(\mathrm{OH}) \mathrm{D}$ concentration decreased below $\leq 30 \mathrm{nmol} / \mathrm{L}$. The decrease in relative production of serum $24,25(\mathrm{OH})_{2} \mathrm{D}$ in response to the decline in $25(\mathrm{OH}) \mathrm{D}$ suggests down-regulation of CYP24A1.

1,25(OH) $)_{2}$ D:24, 25(OH) $)_{2}$ D VMR and vitamin D status. Vitamin D status, as indicated by $25(\mathrm{OH}) \mathrm{D}$ concentrations, revealed an exponential negative correlation $\left(\mathrm{r}^{2} \mathrm{Exp}=0.582\right)$ with $1,25(\mathrm{OH})_{2} \mathrm{D}: 24,25(\mathrm{OH})_{2} \mathrm{D}$ VMR (Fig. 1d). Post hoc analysis identified a significant increase in $1,25(\mathrm{OH})_{2} \mathrm{D}: 24,25(\mathrm{OH})_{2} \mathrm{D}$ VMR at $25(\mathrm{OH})$ $\mathrm{D} \leq 60 \mathrm{nmol} / \mathrm{L}$ (Fig. 3). Using the Jacobson and Truax ${ }^{13,14}$ method to determine the cut-off value for clinically significant change ${ }^{7}$, we estimated $1,25(\mathrm{OH})_{2} \mathrm{D}: 24,25(\mathrm{OH})_{2} \mathrm{D}$ VMR of $\geq 35$ to be the predictive threshold value for vitamin $\mathrm{D}$ insufficiency, and $\geq 51$ to be predictive threshold for vitamin $\mathrm{D}$ deficiency. The threshold values were determined from subject samples collected in the winter months (January to April) due to the seasonal variation of 25(OH)D. Receiver Operating Characteristic (ROC) curves generated from data collected between January to April produced area under the curve (AUC) values of 0.88 and 0.86 , indicating the VMR cut-offs are excellent at discriminating individuals with vitamin $\mathrm{D}$ insufficiency and deficiency. The $1,25(\mathrm{OH})_{2} \mathrm{D}: 24,25(\mathrm{OH})_{2} \mathrm{D}$ VMR at 

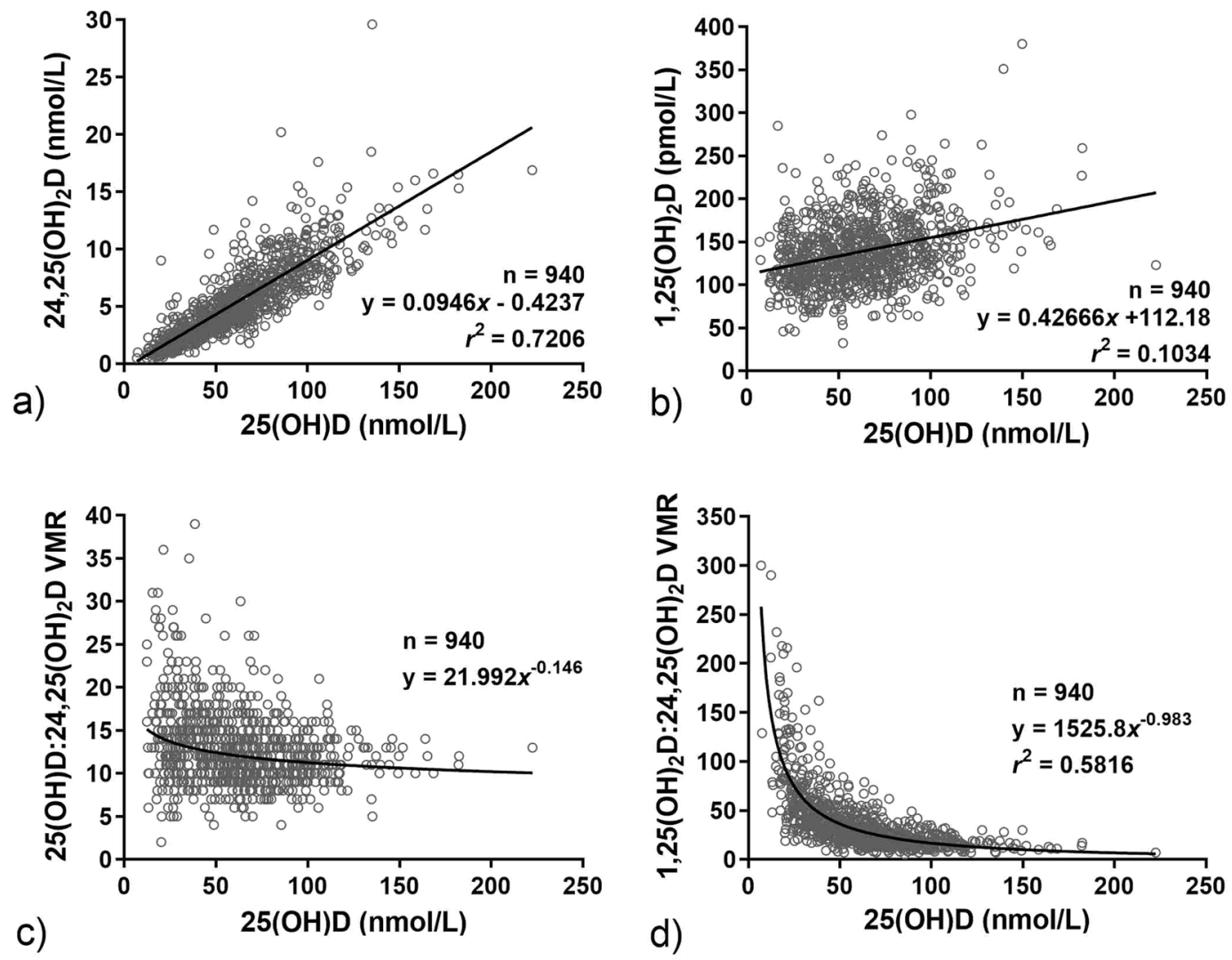

Figure 1. Non-parametric correlations of (a) $24,25(\mathrm{OH})_{2} \mathrm{D}(\mathbf{b}) 1,25(\mathrm{OH})_{2} \mathrm{D}(\mathbf{c}) 25(\mathrm{OH}) \mathrm{D}: 24,25(\mathrm{OH})_{2} \mathrm{D}$ VMR and $(\mathbf{d}) 1,25(\mathrm{OH})_{2} \mathrm{D}: 24,25(\mathrm{OH})_{2} \mathrm{D}$ VMR, against their respective $25(\mathrm{OH}) \mathrm{D}$ concentration. Solid lines in $(\mathbf{a}, \mathbf{b})$ represent linear regression line. LOWESS fitted curve in (c,d) (99\% point fit). The mean $24,25(\mathrm{OH})_{2} \mathrm{D}$ and $1,25(\mathrm{OH})_{2} \mathrm{D}$ concentrations, $25(\mathrm{OH}) \mathrm{D}: 24,25(\mathrm{OH})_{2} \mathrm{D}$ VMR and $1,25(\mathrm{OH})_{2} \mathrm{D}: 24,25(\mathrm{OH})_{2} \mathrm{D}$ VMR represent $8.7 \%, 222.4 \%, 20.8 \%$ and $60.9 \%$ of their respective $25(\mathrm{OH}) \mathrm{D}$ concentration. Assay lower limit of quantification (LLoQ): $25(\mathrm{OH}) \mathrm{D}$ and $24,25(\mathrm{OH})_{2} \mathrm{D}=0.1 \mathrm{nmol} / \mathrm{L}, 1,25(\mathrm{OH})_{2} \mathrm{D}=12 \mathrm{pmol} / \mathrm{L}$.

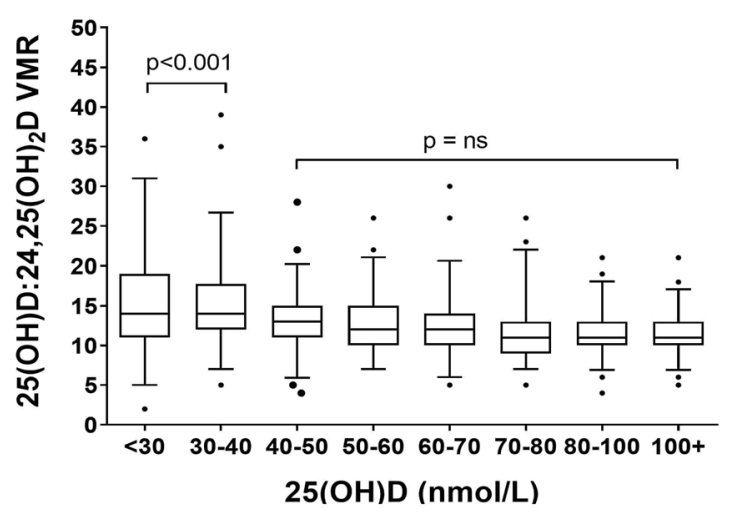

Figure 2. Distribution of 25(OH)D:24,25(OH $)_{2} \mathrm{D}$ VMR by $25(\mathrm{OH}) \mathrm{D}$ intervals. Each interval contains an equal number of subjects to illustrate the significantly elevated ratio in those with serum $25(\mathrm{OH}) \mathrm{D} \leq 50 \mathrm{nmol} / \mathrm{L}$. Box and whiskers represent the median, interquartile range and $95 \%$ population intervals.

35 and 51 achieved true positive rate (sensitivity) at $80 \%$ and $78 \%$, respectively, and false positive rate (specificity) of $82 \%$ and $74 \%$, respectively (Fig. $4 a, b)$.

1,25(OH) $)_{2}$ D:24, 25(OH) $)_{2}$ D VMR and PTH. Circulating PTH is influenced by $25(\mathrm{OH}) \mathrm{D}$ and $1,25(\mathrm{OH})_{2} \mathrm{D}$, and vice versa. We hypothesised that PTH concentration changes with $1,25(\mathrm{OH})_{2} \mathrm{D}: 24,25(\mathrm{OH})_{2} \mathrm{D}$ VMR and 25(OH)D. To test our hypothesis, median PTH concentrations were established from grid analysis based on groupings of $1,25(\mathrm{OH})_{2} \mathrm{D}: 24,25(\mathrm{OH})_{2} \mathrm{D}$ VMR and $25(\mathrm{OH}) \mathrm{D}$ in ascending order (Table 2). A decrease in PTH concentration was observed from the high $1,25(\mathrm{OH})_{2} \mathrm{D}: 24,25(\mathrm{OH})_{2} \mathrm{D}$ VMR $(100+)$ and low $25(\mathrm{OH}) \mathrm{D}(<30$ 


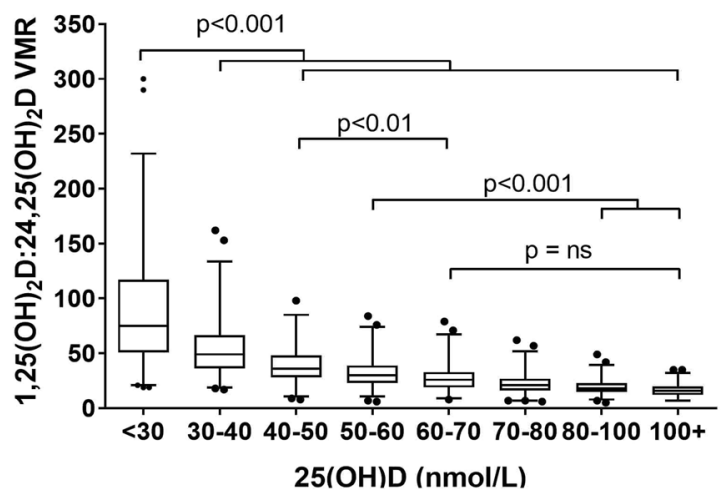

Figure 3. Distribution of $1,25(\mathrm{OH})_{2} \mathrm{D}: 24,25(\mathrm{OH})_{2} \mathrm{D}$ VMR by $25(\mathrm{OH}) \mathrm{D}$ intervals. It demonstrates the exponential increase in $1,25(\mathrm{OH})_{2} \mathrm{D}: 24,25(\mathrm{OH})_{2} \mathrm{D}$ VMR with the decrease in serum $25(\mathrm{OH}) \mathrm{D}$. Box and whiskers represent the median, interquartile range and $95 \%$ population intervals. Each interval contains an equal number of subjects.
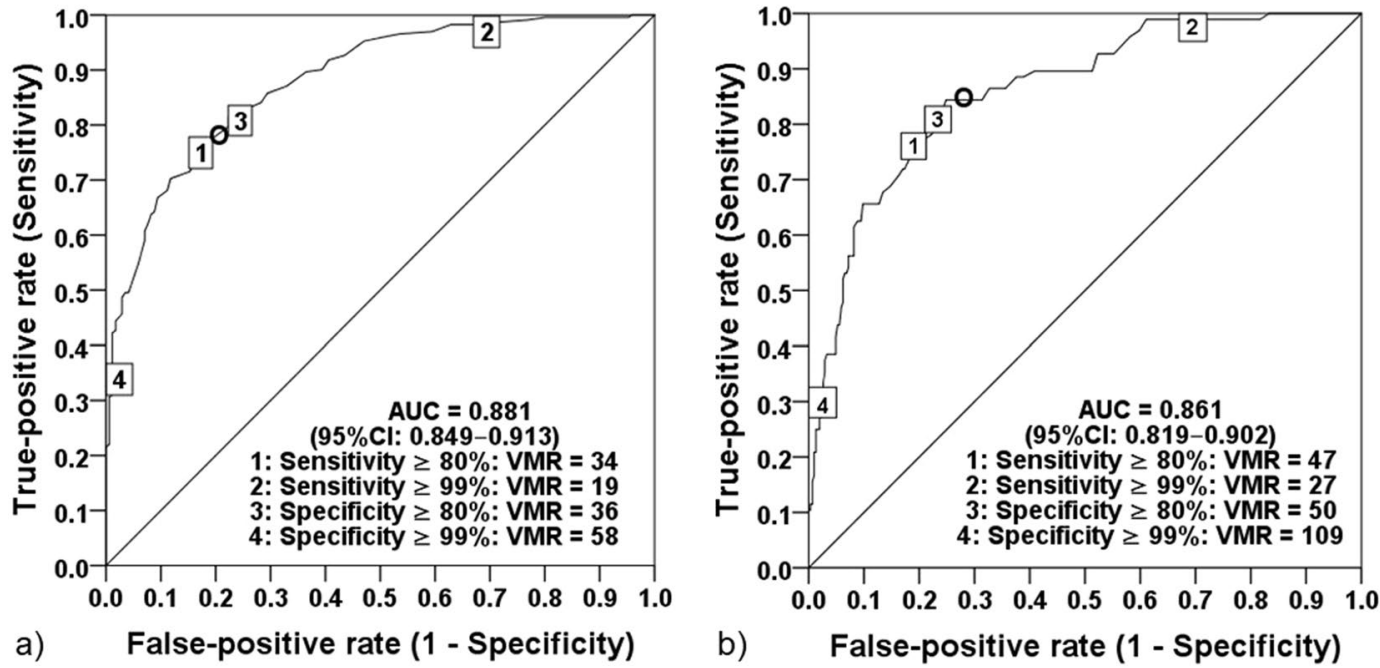

Figure 4. Diagnostic performance of $1,25(\mathrm{OH})_{2} \mathrm{D}: 24,25(\mathrm{OH})_{2} \mathrm{D}$ VMR in the assessment of vitamin $\mathrm{D}$ status during winter months (Jan-April) $(\mathrm{n}=402)$. Receiver Operating Characteristic (ROC) curve depicts diagnostic sensitivity and specificity levels. $(\mathbf{O})$ represents decision threshold for $($ a) vitamin $\mathrm{D}$ replete (i.e. $25(\mathrm{OH}) \mathrm{D} \geq 50$ $\mathrm{nmol} / \mathrm{L}), 1,25(\mathrm{OH})_{2} \mathrm{D}: 24,25(\mathrm{OH})_{2} \mathrm{D}$ VMR threshold value of 35 (sensitivity $=80 \%$, specificity $\left.=78 \%\right),(\mathbf{b})$ vitamin D insufficiency (i.e. $25(\mathrm{OH}) \mathrm{D} \geq 30 \mathrm{nmol} / \mathrm{L}), 1,25(\mathrm{OH})_{2} \mathrm{D}: 24,25(\mathrm{OH})_{2} \mathrm{D}$ VMR threshold value of 51 (sensitivity $=82 \%$, specificity $=74 \%$ ). The diagonal lines represent the line of no discrimination.

\begin{tabular}{|l|l|l|l|l|l|}
\hline \multirow{2}{*}{ Median PTH, pmol/L } & \multicolumn{2}{l}{$\mathbf{2 5}(\mathbf{O H}) \mathbf{D}, \mathbf{n m o l} / \mathbf{L}$} \\
\cline { 3 - 7 } & & $<\mathbf{3 0}$ & $\mathbf{3 0 - 5 0}$ & $\mathbf{5 1 - 1 0 0}$ & $\mathbf{1 0 0 +}$ \\
\hline \multirow{3}{*}{$1,25(\mathrm{OH})_{2} \mathrm{D}: 24,25(\mathrm{OH})_{2} \mathrm{D}$ VMR } & $100+$ & $5.7(0.2)^{*}$ & $5.4(0.5)^{*}$ & - & - \\
\cline { 2 - 7 } & $51-100$ & $4.3(0.2)^{*}$ & $3.8(0.2)$ & $3.4(0.3)$ & - \\
\cline { 2 - 7 } & $30-50$ & $4.0(0.2)^{*}$ & $3.7(0.1)$ & $3.5(0.1)$ & $2.7(0.2)^{*}$ \\
\cline { 2 - 7 } & $<30$ & $3.8(0.3)$ & $3.9(0.1)$ & $3.3(0.1)^{*}$ & $3.2(0.1)^{*}$ \\
\hline
\end{tabular}

Table 2. Median (SEM) PTH concentrations in categories of increasing 1,25(OH) 2 D:24,25(OH) 2 D VMR and 25(OH)D. One-way ANOVA showed PTH concentrations decreased significantly $(\mathrm{p}>0.001)$ from high $1,25(\mathrm{OH})_{2} \mathrm{D}: 24,25(\mathrm{OH})_{2} \mathrm{D}$ VMR/low $25(\mathrm{OH}) \mathrm{D}$ to low $1,25(\mathrm{OH})_{2} \mathrm{D}: 24,25(\mathrm{OH})_{2} \mathrm{D}$ VMR/high 25(OH)D. *Denotes significance at the $\mathrm{p}<0.05$ level.

$\mathrm{nmol} / \mathrm{L})$ group, to the low $1,25(\mathrm{OH})_{2} \mathrm{D}: 24,25(\mathrm{OH})_{2} \mathrm{D}$ VMR $(<30)$ and high $25(\mathrm{OH}) \mathrm{D}(100+\mathrm{nmol} / \mathrm{L})$ group. Using Kruskal-Wallis independent non-parametric analysis to test the distribution of PTH across all groups, a highly significant $(\mathrm{p}>0.001)$ change in PTH concentration was found across the $1,25(\mathrm{OH})_{2} \mathrm{D}: 24,25(\mathrm{OH})_{2} \mathrm{D}$ 

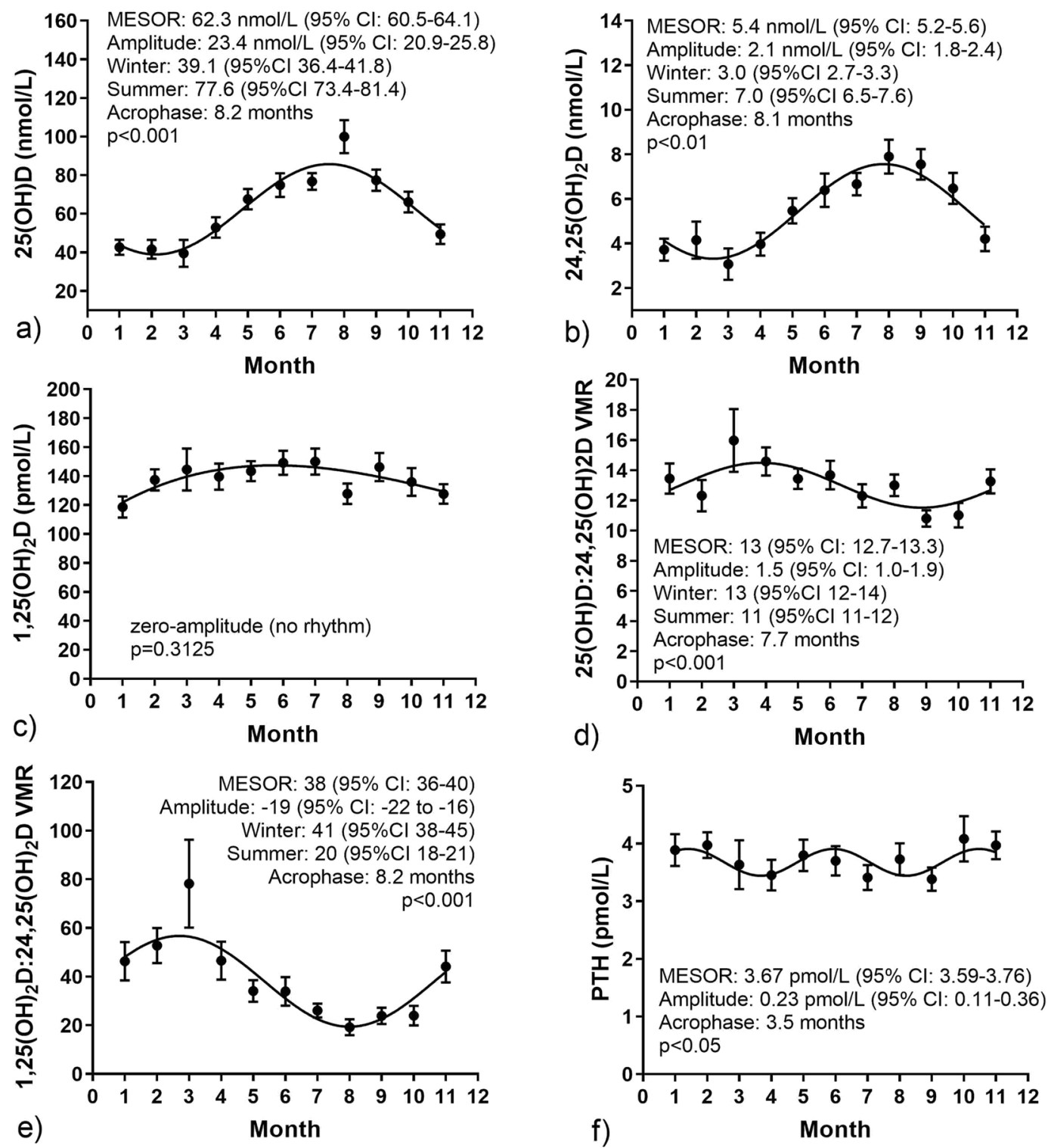

Figure 5. Cosinor-fit circannual rhythm for (a) $25(\mathrm{OH}) \mathrm{D},(\mathbf{b}) 24,25(\mathrm{OH})_{2} \mathrm{D},(\mathbf{c}) 1,25(\mathrm{OH})_{2} \mathrm{D},(\mathbf{d}) 25(\mathrm{OH})$ $\mathrm{D}: 24,25(\mathrm{OH})_{2} \mathrm{D},(\mathbf{e}) 1,25(\mathrm{OH})_{2} \mathrm{D}: 24,25(\mathrm{OH})_{2} \mathrm{D}$, (f) PTH. Error bars represent $95 \% \mathrm{CI}$.

VMR and 25(OH)D categories, hence the null hypothesis was rejected. Using Spearman's rank correlation coefficient (2-tailed) to assess monotonic functions between variables, significant positive correlations were evident between VMRs and PTH $\left(1,25(\mathrm{OH})_{2} \mathrm{D}: 24,25(\mathrm{OH})_{2} \mathrm{D}\right.$ VMR rho $=0.249, \mathrm{p}>0.001$ and $25(\mathrm{OH}) \mathrm{D}: 24,25(\mathrm{OH})_{2} \mathrm{D}$ VMR rho $=0.134, \mathrm{p}>0.001)$; whereas vitamin $\mathrm{D}$ metabolites showed significant negative correlations with PTH $\left(25(\mathrm{OH}) \mathrm{D}\right.$ rho $=-0.287, \mathrm{p}>0.001,24,25(\mathrm{OH})_{2} \mathrm{D}$ rho $=-0.282, \mathrm{p}>0.001$ and $1,25(\mathrm{OH})_{2} \mathrm{D}$ rho $=-0.87$, $\mathrm{p}>0.001)$. The statistical significance remain unchanged after adjustment for BMD and BMI as covariates.

Circannual variations in vitamin D metabolites and VMRs. Cosinor-fit curves (Fig. 5) show significant circannual rhythm for 25(OH)D ( $\mathrm{p}<0.001), 24,25(\mathrm{OH})_{2} \mathrm{D}(\mathrm{p}<0.01), 25(\mathrm{OH}) \mathrm{D}: 24,25(\mathrm{OH})_{2} \mathrm{D}$ VMR $(\mathrm{p}<0.001), 1,25(\mathrm{OH})_{2} \mathrm{D}: 24,25(\mathrm{OH})_{2} \mathrm{D}$ VMR $(\mathrm{p}<0.001)$ and PTH $(\mathrm{p}<0.05)$. No significant rhythm was observed for $1,25(\mathrm{OH})_{2} \mathrm{D}(\mathrm{p}=3.125)$. The rhythm observed for $25(\mathrm{OH}) \mathrm{D}$ is consistent with previous reports ${ }^{15,16}$. $24,25(\mathrm{OH})_{2} \mathrm{D}$ showed a similar peak (July-Aug) and nadir (Jan-Mar) pattern as for 25(OH)D. 25(OH) D:24,25(OH $)_{2} \mathrm{D}$ VMR and $1,25(\mathrm{OH})_{2} \mathrm{D}: 24,25(\mathrm{OH})_{2} \mathrm{D}$ VMR exhibited patterns in the opposite direction, with peak (Mar-April) and nadir (Aug-Sept) suggesting that the production of $24,25(\mathrm{OH})_{2} \mathrm{D}$ is relatively higher during summer/early autumn months. Acrophase, defined as the lag time between rhythm-adjusted mean and peak cycle value, was on average (SD) of 8.1(0.3) months for all vitamin D metabolites except for $1,25(\mathrm{OH})_{2} \mathrm{D}$. A low amplitude, circasemiannual PTH secretory rhythm was observed, with an acrophase of 3.5 months. 


\section{Discussion}

This is the first study to demonstrate a relationship between serum concentrations of $25(\mathrm{OH}) \mathrm{D}$ and $1,25(\mathrm{OH})_{2} \mathrm{D}$ when expressed as a relative ratio with serum $24,25(\mathrm{OH})_{2} \mathrm{D}$. We provide evidence that the conversion of $25(\mathrm{OH})$ $\mathrm{D}$ to $1,25(\mathrm{OH})_{2} \mathrm{D}$ is associated with the catabolism of $25(\mathrm{OH}) \mathrm{D}$ to $24,25(\mathrm{OH})_{2} \mathrm{D}$, which can be assessed by the measurement of serum $24,25(\mathrm{OH})_{2} \mathrm{D}$ and its derived VMR.

The inverse exponential correlation between $1,25(\mathrm{OH})_{2} \mathrm{D}: 24,25(\mathrm{OH})_{2} \mathrm{D}$ VMR and $25(\mathrm{OH}) \mathrm{D}$ provides insight into the dynamics of vitamin D metabolites in healthy, young adults; when vitamin $\mathrm{D}$ status is sufficient, serum concentrations of $1,25(\mathrm{OH})_{2} \mathrm{D}$ and $24,25(\mathrm{OH})_{2} \mathrm{D}$ are maintained in relative proportion and showed no significant change beyond the sufficient threshold. In contrast, when vitamin D status is insufficient, a progressive and highly significant increase in $1,25(\mathrm{OH})_{2} \mathrm{D}: 24,25(\mathrm{OH})_{2} \mathrm{D}$ VMR is evidence that the production of serum $1,25(\mathrm{OH})_{2} \mathrm{D}$ is favoured over $24,25(\mathrm{OH})_{2} \mathrm{D}$ as the availability of vitamin $\mathrm{D}$ precursors in circulation diminishes. Our data imply two possible regulatory functions of the $24,25(\mathrm{OH})_{2} \mathrm{D}$ pathway; in hypervitaminosis, the pathway is 'switched on' to allow excess $25(\mathrm{OH}) \mathrm{D}$ to be converted to $24,25(\mathrm{OH})_{2} \mathrm{D}$. The 24 -hydroxylase pathway results in the formation of calcitroic acid for excretion. In hypovitaminosis, the $24,25(\mathrm{OH})_{2} \mathrm{D}$ pathway is partially inactivated to conserve $25(\mathrm{OH}) \mathrm{D}$ and to maintain an adequate supply of substrate for conversion to $1,25(\mathrm{OH})_{2} \mathrm{D}$. Although the biological activity of $24,25(\mathrm{OH})_{2} \mathrm{D}$ is yet to be fully elucidated, its role in vitamin $\mathrm{D}$ catabolism appears certain. Low serum concentrations of $24,25(\mathrm{OH})_{2} \mathrm{D}$ and elevated $25(\mathrm{OH}) \mathrm{D}: 24,25(\mathrm{OH})_{2} \mathrm{D}$ VMR is useful in identifying patients with loss-of-function CYP24A1 mutations ${ }^{8,9,17}$. In our previous publication ${ }^{7}$, we described a case of biallelic CYP24A1 mutation in a patient presenting with hypercalcaemia, elevated serum $1,25(\mathrm{OH})_{2} \mathrm{D}$ concentration $(293 \mathrm{pmol} / \mathrm{L}$, reference range $43-144 \mathrm{pmol} / \mathrm{L})$, and elevated $25(\mathrm{OH}) \mathrm{D}: 24,25(\mathrm{OH})_{2} \mathrm{D}$ VMR of 32 . On diagnosis, the patient's $1,25(\mathrm{OH})_{2} \mathrm{D}: 24,25(\mathrm{OH})_{2} \mathrm{D}$ VMR was 212 (1.6 times the upper 97.5th percentile of 132 ), which was attributed to supplementation with vitamin $\mathrm{D}$. One month after treatment for hypercalcaemia and cessation of vitamin $\mathrm{D}$ supplement, serum $1,25(\mathrm{OH})_{2} \mathrm{D}$ was within the reference range, the $1,25(\mathrm{OH})_{2} \mathrm{D}: 24,25(\mathrm{OH})_{2} \mathrm{D}$ VMR decreased to 130 (below the $97^{\text {th }}$ percentile), and the $25(\mathrm{OH}) \mathrm{D}: 24,25(\mathrm{OH})_{2} \mathrm{D}$ VMR remained elevated at 35 .

A major finding of this study was the link between the vitamin D metabolites and VMRs with the distribution of PTH. To the best of our knowledge, this is the first such report in a human population study. It is widely accepted that the PTH concentration is associated with $25(\mathrm{OH}) \mathrm{D}$, but not with the active $1,25(\mathrm{OH})_{2} \mathrm{D}$. This is due to the tight regulatory mechanisms, and the regulatory processes that take place via the vitamin $\mathrm{D}$ receptor (VDR) to activate intracellular transport of calcium and stimulate PTH secretion. Using our $1,25(\mathrm{OH})_{2} \mathrm{D}: 24,25(\mathrm{OH})_{2} \mathrm{D}$ VMR and 25(OH)D model (Fig. 1d), we have shown that individuals with low $25(\mathrm{OH}) \mathrm{D}(\leq 50 \mathrm{nmol} / \mathrm{L})$, normal $1,25(\mathrm{OH})_{2} \mathrm{D}$ but high $1,25(\mathrm{OH})_{2} \mathrm{D}: 24,25(\mathrm{OH})_{2} \mathrm{D}$ VMR $(\geq 101)$ have significantly higher PTH concentration than those at the opposite end of the spectrum. An interpretation of our finding supports a biological role of $24,25(\mathrm{OH})_{2} \mathrm{D}$ other than as a catabolic metabolite of vitamin D. Relative high production of $24,25(\mathrm{OH})_{2} \mathrm{D}$ may reduce the bioactivity of $25(\mathrm{OH}) \mathrm{D}$ and $1,25(\mathrm{OH})_{2} \mathrm{D}$, particularly extra-renal production of $1,25(\mathrm{OH})_{2} \mathrm{D}$, to down-regulate the secretion of PTH whilst maintaining $1,25(\mathrm{OH})_{2} \mathrm{D}$ concentrations within the strict boundaries required for appropriate calcium homeostasis. Relatively low $24,25(\mathrm{OH})_{2} \mathrm{D}$ could enhance the anabolic effects of vitamin D metabolism, by stimulating PTH production. The biological action of $24,25(\mathrm{OH})_{2} \mathrm{D}$ on the inhibition of PTH secretion was first reported in animal and in vitro models in the late seventies ${ }^{18,19}$. More recently there is increasing evidence supporting physiological functions of $24,25(\mathrm{OH})_{2} \mathrm{D}$ on bone and cartilage ${ }^{20-22}$ in promoting fracture healing, and protection against cartilage damage. The existence of a $24,25(\mathrm{OH})_{2} \mathrm{D}$-specific nuclear or membrane receptor has been reported ${ }^{23}$, but its function has yet to be elucidated. Given that CYP24A1, the enzyme responsible for the production of $24,25(\mathrm{OH})_{2} \mathrm{D}$, is present in most tissues with VDR, understanding the mechanisms controlling the production of $24,25(\mathrm{OH})_{2}$ D relative to other vitamin D metabolites may have significance beyond vitamin D catabolism, potentially shaping vitamin D supplementation strategies.

Mapping the circannual rhythms of vitamin D metabolites and VMRs is an important component of this study. We have published reports on longitudinal studies (Macdonald et al.) ${ }^{15,16,24}$, decribing the changes in serum $25(\mathrm{OH}) \mathrm{D}$ and $24,25(\mathrm{OH})_{2} \mathrm{D}$ throughout a year in vitamin $\mathrm{D}$ supplemented or non-supplemented subjects. In the VICtORy (Vitamin D and CardiOvascularRisk) ${ }^{15}$ and VICtORy RECALL ${ }^{16}$ randomised controlled studies performed using a group of postmenopausal women residing in the northeast of UK, the placebo group showed a two-fold increase in serum $25(\mathrm{OH}) \mathrm{D}$ in peak summer months (July-August), compared to the nadir in late winter months (January-March). Our younger cohort of healthy individuals in this study showed similar trends; $24,25(\mathrm{OH})_{2} \mathrm{D}$ had a propensity to fluctuate with $25(\mathrm{OH}) \mathrm{D}$ throughout the year, with changes between summer and winter months, as indicated by a lower $25(\mathrm{OH}) \mathrm{D}: 24,25(\mathrm{OH})_{2} \mathrm{D}$ VMR during January to March than during July to September. Serum $1,25(\mathrm{OH})_{2} \mathrm{D}$ displayed no rhythm and was within the reference range throughout the year. The circannual variation of $1,25(\mathrm{OH})_{2} \mathrm{D}: 24,25(\mathrm{OH})_{2} \mathrm{D}$ VMR was dependent on $24,25(\mathrm{OH})_{2} \mathrm{D}$, with a peak-to-nadir difference of 19; such sharp demarcation between seasons would inevitably create uncertainty when using $1,25(\mathrm{OH})_{2} \mathrm{D}: 24,25(\mathrm{OH})_{2} \mathrm{D}$ VMR in diagnostic decision-making. In contrast, $25(\mathrm{OH}) \mathrm{D}: 24,25(\mathrm{OH})_{2} \mathrm{D}$ VMR is less susceptible to seasonal fluctuation, allowing the use of the VMR with fixed reference intervals irrespective of the time of the year.

One strength of our data is the chosen cohort; with participants attending blood sampling visits at strictly controlled time intervals and that the vitamin D metabolites were measured using gold-standard methodologies. The participants are well-defined, largely from a similar social-economic background, and exposed to the same level of fitness training, diet, and frequency of outdoor activities. The relative homogeneity of the subjects of our study population in combination with our inclusion criteria allowed us to confidently form a reference population and identify important changes in analytes. The limitations are that our findings are observational and based on baseline sampling at the start of training. Also, our cohort represents young adults of Caucasian extraction (92.9\%), and cannot be extrapolated to the wider population of mixed ethnicity. The predictive threshold values were established based on the equivalent vitamin D status as described by IOM, and not based on our own data as the study was not randomly controlled. We did not measure vitamin D binding protein (VDBP) and free 


\begin{tabular}{|l|l|l|}
\hline \multirow{2}{*}{$\mathbf{n}$} & Male & Female \\
\cline { 2 - 3 } & $\mathbf{6 5 2}$ & $\mathbf{2 8 8}$ \\
\hline Mean age, years (range) & $21.7(18-32)$ & $22.1(18-32)$ \\
\hline Height, $\mathrm{m}$ & $1.77(6.4)$ & $1.66(5.9)$ \\
\hline body mass, kg & $75.9(9.8)$ & $64.7(7.5)$ \\
\hline Body mass index $(\mathrm{BMI})$ & $24.1(2.6)$ & $23.4(3.3)$ \\
\hline Total body BMD $\left(\mathrm{g} / \mathrm{cm}^{2}\right)$ & $1.24(0.10)$ & $1.16(0.09)$ \\
\hline
\end{tabular}

Table 3. Baseline characteristics of the subjects included in the study. *Data shown in mean \pm SD otherwise stated.

25(OH)D due to the ethnic homogeneity of our population, and we did not exclude factors that may influence VDBP levels (e.g. oral contraceptive use in female recruits). We also acknowledge the use of VMR in reverse (i.e. $24,25(\mathrm{OH})_{2} \mathrm{D}: 25(\mathrm{OH}) \mathrm{D}$ - as described $\left.\mathrm{in}^{25}\right)$ can be an alternative approach to express the relationship. Lastly, the sample data used in the current study is a subset of the Army cohort used to establish the reference intervals of serum $24,25(\mathrm{OH})_{2} \mathrm{D}^{7}$. Whilst there is a degree of overlap, the overall content of this report, analytical approaches and conclusions described are independent of the previous report.

In conclusion, the present analysis characterises the absolute and relative concentrations of the active and catabolic form of vitamin D metabolites in a well-defined young, healthy and physically fit population. The use of VMRs provides insight into the metabolic pathway and the variations exhibited throughout the year. We propose a three-dimensional model incorporating $1,25(\mathrm{OH})_{2} \mathrm{D}, 24,25(\mathrm{OH})_{2} \mathrm{D}$ and $25(\mathrm{OH}) \mathrm{D}$ measurements and report a strong correlation between metabolites that are linked with PTH. Such modelling could help establish vitamin D-adjusted PTH reference intervals, and ultimately contribute to the goal of a "Treat to target" approach to vitamin D supplementation.

\section{Methods}

Study design. The study received ethics approval from the UK Ministry of Defence Research Ethics Committee and was conducted in accordance with the Declaration of Helsinki (2013). The characteristics of the subjects included in the study are shown in Table 3. In total, 2252 new British Army recruits at the start of phase one training volunteered for the study. Written informed consent was obtained from all study participants, and each required to complete a detailed health questionnaire, including medical history and the use of supplements. All recruits undertook physical and cognitive testing, and a detailed medical examination prior to joining the army. The British Army entry requirements restrict individuals with chronic medical conditions; therefore, our study population represents a medically screened, disease-free, and physically fit population. In the analysis, we excluded individuals who reported the use of calcium and vitamin D supplements (including multivitamins and cod liver oil), and excluded participants who reported injury and illness prior to recruitment; conditions such as being underweight, eating disorders, or those with a history of bone fracture. 940 participants were included in the final statistical analyses. The majority of participants were from Caucasian population (92.9\%), with a minority from a diverse ethnicity (Asian $1.6 \%$, Black $1.7 \%$, Chinese $0.1 \%$, mixed $3 \%$, others $0.7 \%$ ).

Sample collection. Blood samples were collected during the period of June 2014 and March 2016. Venous blood samples were obtained from the participants at the start of 14-week long basic military training. Sample collections were scheduled on a monthly basis to balance the seasonal variations. Each intake comprised, on average (range), 86 (43-120) participants. Blood samples were collected into serum gel separator tube and EDTA plasma container (BD Vacutainer). Samples were centrifuged immediately after collection at 3,000 $\times \mathrm{g}$ for $10 \mathrm{~min}$ utes. Plasma/serum layers were aliquoted into a separate polystyrene tube and stored at $-20^{\circ} \mathrm{C}$ until analysis. All samples were anonymised to the researchers at the point of access.

Ethical approval. The study was approved by the UK Ministry of Defence research ethics committee (MODREC 165/Gen/10 and 692/MoDREC/15). ClinicalTrials.gov Identifier NCT02416895.

LC-MS/MS measurements of serum 25(OH)D and $24,25(\mathrm{OH})_{2} \mathrm{D}$. Liquid chromatography tandem mass spectrometry (LC-MS/MS) was performed as described ${ }^{7,26-28}$. The method quantified $25(\mathrm{OH}) \mathrm{D} 3,25(\mathrm{OH})$ $\mathrm{D} 2,24,25(\mathrm{OH})_{2} \mathrm{D} 3$ and $24,25(\mathrm{OH})_{2} \mathrm{D} 2$ simultaneously from a single injection. $25(\mathrm{OH}) \mathrm{D} 3$ and $25(\mathrm{OH}) \mathrm{D} 2$ were calibrated using commercial standards (Chromsystems, München, Germany) traceable to standard reference material SRM972a from the National Institute of Science and Technology (NIST) ${ }^{25,29}$, and showed linearity between $0-200 \mathrm{nmol} / \mathrm{L}$. The inter/intra-assay coefficient of variation (CV) was $\leq 9 \%$, the lower limit of quantification (LLoQ) of $0.1 \mathrm{nmol} / \mathrm{L}$. The assay showed $<8 \%$ accuracy bias against NIST reference method on the Vitamin D external quality assessment (DEQAS) scheme. $24,25(\mathrm{OH})_{2} \mathrm{D} 3$ and $24,25(\mathrm{OH})_{2} \mathrm{D} 2$ were calibrated using in-house spiked standards traceable to NIST SRM972a. The assay is linear between $0-25 \mathrm{nmol} / \mathrm{L}$; inter/ intra-assay CV was $\leq 11 \%$, LLoQ of $0.1 \mathrm{nmol} / \mathrm{L}$ for $24,25(\mathrm{OH})_{2} \mathrm{D} 3$ and $0.8 \mathrm{nmol} / \mathrm{L}$ for $24,25(\mathrm{OH})_{2} \mathrm{D} 2$.

Measurements of serum 1,25(OH) $)_{2}$ D. The DiaSorin LIAISON ${ }^{\circledR}$ XL $1,25(\mathrm{OH})_{2} \mathrm{D}$ chemiluminescent immunoassay (Stillwater, MN, USA) method was used. The sandwich assay utilises a recombinant fusion protein for the capture of $1,25(\mathrm{OH})_{2} \mathrm{D}$ molecule and a murine monoclonal antibody detection system. The assay measures total $1,25(\mathrm{OH})_{2} \mathrm{D}$ between $12-480 \mathrm{pmol} / \mathrm{L}$, the inter/intra-assay $\mathrm{CV}$ was $\leq 9.2 \%$. The mean assay recovery was 
$94 \pm 2 \%$. On the Vitamin D external quality assessment (DEQAS) scheme, the assay showed $\leq 8.5 \%$ bias against method-specific mean and $\leq 9.1 \%$ bias against all method mean.

Biochemical analysis. Intact PTH and albumin-adjusted calcium (ACa) were analysed on the COBAS ${ }^{\circledR}$ (Roche Diagnostics, Mannheim, Germany) platform. PTH in EDTA plasma was measured using electrochemiluminescence immunoassay (ECLIA), the inter-assay CV was $\leq 3.8 \%$ across the analytical range of $1.2-5000 \mathrm{pg} / \mathrm{mL}$. Total calcium and albumin were measured based on spectrophotometric methods. The inter-assay CV for Ca was $\leq 1.6 \%$, albumin was $\leq 1.1 \%$. ACa value is calculated using the equation $A C a=(-0.8 \times[$ Albumin $]-4)+[$ Total Ca $]$.

Statistical analysis. Descriptive statistics, scatterplots, ROC and LOWESS curves were constructed and analysed by Statistical Package for the Social Science (SPSS) version 22.0.0.1 (IBM, New York, USA) and GraphPad Prism 7 (GraphPad, San Diego, CA, USA). Univariate and multivariable linear regression analyses and one-way ANOVA were used to estimate associations. LOWESS curve fitting was used to explore nonlinear relationships between variables. Kruskal-Wallis independent analysis and Spearman's rho were used to establish associations in non-parametric variables. Statistical significance was defined as $p<0.05$. Frequency distribution histograms of the data were visually examined and checked for transcriptional and pre/post analytical errors before exclusion for statistical analysis. Confidence interval (CI) was established at $95 \%$ of the population. Circannual rhythm analysis was performed by population-mean cosinor analysis, based on cosinor-fitting equation $y=$ MESOR + Amplitude $\times \cos ($ Frequency $(x)+$ acrophase). Midline estimate statistic of rhythm (MESOR), defined as the rhythm-adjusted mean value. Acrophase is the difference (time) between MESOR and peak value in the cosine curve.

\section{Data Availability}

The datasets generated and analysed during the current study are not publicly available due to data protection. Data request is subject to approval by the UK Ministry of Defence.

\section{References}

1. Bolland, M. J., Grey, A. \& Avenell, A. Effects of vitamin D supplementation on musculoskeletal health: a systematic review, metaanalysis, and trial sequential analysis. The lancet. Diabetes \& endocrinology (2018).

2. Martineau, A. R. et al. Vitamin D supplementation to prevent acute respiratory tract infections: systematic review and meta-analysis of individual participant data. BMJ 356, i6583 (2017).

3. Khaw, K. T. et al. Effect of monthly high-dose vitamin D supplementation on falls and non-vertebral fractures: secondary and posthoc outcomes from the randomised, double-blind, placebo-controlled ViDA trial. The lancet. Diabetes \& endocrinology 5, 438-447 (2017).

4. Ross, A. C. et al. The 2011 report on dietary reference intakes for calcium and vitamin D from the Institute of Medicine: what clinicians need to know. J Clin Endocrinol Metab 96, 53-58 (2011).

5. Francis, R. M. et al. National Osteoporosis Society practical clinical guideline on vitamin D and bone health. Maturitas 80, 119-121 (2015).

6. Levin, A. et al. Prevalence of abnormal serum vitamin D, PTH, calcium, and phosphorus in patients with chronic kidney disease: results of the study to evaluate early kidney disease. Kidney Int 71, 31-38 (2007).

7. Tang, J. C. Y. et al. Reference intervals for serum 24,25-dihydroxyvitamin D and the ratio with 25 -hydroxyvitamin D established using a newly developed LC-MS/MS method. J Nutr Biochem 46, 21-29 (2017).

8. Molin, A. et al. CYP24A1 Mutations in a Cohort of Hypercalcemic Patients: Evidence for a Recessive Trait. J Clin Endocrinol Metab 100, E1343-1352 (2015).

9. Kaufmann, M. et al. Clinical utility of simultaneous quantitation of 25-hydroxyvitamin D and 24,25-dihydroxyvitamin D by LC-MS/ MS involving derivatization with DMEQ-TAD. J Clin Endocrinol Metab 99, 2567-2574 (2014).

10. Binkley, N. et al. Can vitamin D metabolite measurements facilitate a "treat-to-target" paradigm to guide vitamin D supplementation? Osteoporos Int 26, 1655-1660 (2015).

11. Armbrecht, H. J., Boltz, M. A. \& Hodam, T. L. PTH increases renal 25(OH)D3-1alpha -hydroxylase (CYP1alpha) mRNA but not renal 1,25(OH)2D3 production in adult rats. Am J Physiol Renal Physiol 284, F1032-1036 (2003).

12. Collins, M. T. et al. Fibroblast growth factor-23 is regulated by 1alpha,25-dihydroxyvitamin D. J Bone Miner Res 20, 1944-1950 (2005).

13. Jacobson, N. S., Roberts, L. J., Berns, S. B. \& McGlinchey, J. B. Methods for defining and determining the clinical significance of treatment effects: description, application, and alternatives. J Consult Clin Psychol 67, 300-307 (1999).

14. Jacobson, N. S. \& Truax, P. Clinical significance: a statistical approach to defining meaningful change in psychotherapy research. $J$ Consult Clin Psychol 59, 12-19 (1991).

15. MacDonald, H. M., Wood, A. D., Tang, J. C. \& Fraser, W. D. Comparison of vitamin D(2) and vitamin D(3) supplementation in increasing serum 25-hydroxyvitamin D status: a systematic review and meta-analysis. Am J Clin Nutr 96, 1152-1153, author reply 1153-1154 (2012).

16. Macdonald, H. M. et al. Longevity of daily oral vitamin D3 supplementation: differences in $25 \mathrm{OHD}$ and $24,25(\mathrm{OH}) 2 \mathrm{D}$ observed 2 years after cessation of a 1-year randomised controlled trial (VICtORy RECALL). Osteoporos Int 28, 3361-3372 (2017).

17. Ketha, H., Kumar, R. \& Singh, R. J. LC-MS/MS for Identifying Patients with CYP24A1 Mutations. Clin Chem 62, 236-242 (2016).

18. Chertow, B. S., Baker, G. R., Henry, H. L. \& Norman, A. W. Effects of vitamin D metabolites on bovine parathyroid hormone release in vitro. Am J Physiol 238, E384-388 (1980).

19. Henry, H. L., Taylor, A. N. \& Norman, A. W. Response of chick parathyroid glands to the vitamin D metabolites, 1,25-dihydroxycholecalciferol and 24,25-dihydroxycholecalciferol. J Nutr 107, 1918-1926 (1977).

20. Boyan, B. D. et al. 24R,25-Dihydroxyvitamin D3 Protects against Articular Cartilage Damage following Anterior Cruciate Ligament Transection in Male Rats. PloS one 11, e0161782 (2016).

21. Gal-Moscovici, A., Gal, M. \& Popovtzer, M. M. Treatment of osteoporotic ovariectomized rats with 24,25(OH)2D3. Eur J Clin Invest 35, 375-379 (2005).

22. St-Arnaud, R. \& Glorieux, F. H. 24,25-Dihydroxyvitamin D-active metabolite or inactive catabolite? Endocrinology 139, 3371-3374 (1998).

23. St-Arnaud, R. CYP24A1-deficient mice as a tool to uncover a biological activity for vitamin D metabolites hydroxylated at position 24. J Steroid Biochem Mol Biol 121, 254-256 (2010).

24. Macdonald, H. M. et al. 25-Hydroxyvitamin D Threshold for the Effects of Vitamin D Supplements on Bone Density Secondary Analysis of a Randomized Controlled Trial. J Bone Miner Res (2018). 
25. Wise, S. et al. Interlaboratory Comparison for the Determination of 24,25-Dihydroxyvitamin D(3) in Human Serum Using Liquid Chromatography with Tandem Mass Spectrometry. J AOAC Int (2017).

26. Owens, D. J. et al. Efficacy of High-Dose Vitamin D Supplements for Elite Athletes. Med Sci Sports Exerc 49, 349-356 (2017).

27. Saleh, L. et al. Impact of a single oral dose of 100,000 IU vitamin D3 on profiles of serum 25(OH)D3 and its metabolites 24,25(OH)2D3, 3-epi-25(OH)D3, and 1,25(OH)2D3 in adults with vitamin D insufficiency. Clin Chem Lab Med (2017).

28. Tang, J. et al. Profiles of 25 hydroxyvitamin D and its metabolite 24,25 dihydroxyvitamin D and 1,25 dihydroxyvitamin D in vitamin D3 supplementations studies. In The 43rd Annual European Calcified Tissue Society Congress (Bone Abstracts Vol 5 OP19, Rome, Italy, 2016).

29. Phinney, K. W. et al. Development of an Improved Standard Reference Material for Vitamin D Metabolites in Human Serum. Analytical chemistry 89, 4907-4913 (2017).

\section{Acknowledgements}

The authors would like to acknowledge Samuel Oliver, Mark Ward, Claire Potter, Xin Hui Aw Yong, Alexander Carswell and Daniel Kashi (Bangor University) for the collection of Army samples.

\section{Author Contributions}

J.C.Y.T. wrote the main manuscript text. J.C.Y.T. and S.J. performed data analysis. S.J., J.G., N.P.W., W.D.F. and J.C.Y.T. oversaw the project, interpretation of data, drafting and revising of the manuscript. J.C.Y.T. and the Bioanalytical Facility team performed sample analysis. All authors approved the final version of the manuscript.

\section{Additional Information}

Competing Interests: The authors declare no competing interests.

Publisher's note: Springer Nature remains neutral with regard to jurisdictional claims in published maps and institutional affiliations.

(c) (i) Open Access This article is licensed under a Creative Commons Attribution 4.0 International License, which permits use, sharing, adaptation, distribution and reproduction in any medium or format, as long as you give appropriate credit to the original author(s) and the source, provide a link to the Creative Commons license, and indicate if changes were made. The images or other third party material in this article are included in the article's Creative Commons license, unless indicated otherwise in a credit line to the material. If material is not included in the article's Creative Commons license and your intended use is not permitted by statutory regulation or exceeds the permitted use, you will need to obtain permission directly from the copyright holder. To view a copy of this license, visit http://creativecommons.org/licenses/by/4.0/.

(C) The Author(s) 2019 


\section{Consortia}

Bioanalytical Facility team

Nicole Ball ${ }^{5}$, John Dutton ${ }^{5}$, Holly Nicholls ${ }^{5}$, Isabelle Piec ${ }^{5}$ \& Christopher J. Washbourne ${ }^{5}$

${ }^{5}$ Bioanalytical Facility, Bob Champion Research and Education Building, University of East Anglia, Norwich Research Park, Norwich, UK. 